\title{
THE ANALYSIS ON CANONICAL CORRELATION OF GLOBAL INDEX AND MACRO ECONOMY WITH INDONESIAN COMPOSITE INDEX
}

\author{
Afriza Amir ${ }^{1}$, Isfenti Sadalia ${ }^{2}$, Khaira Amalia Fachruddin ${ }^{3}$ \\ Fakultas Ekonomi, Universitas Prima Indonesia \\ Afrizaamir30@gmail.com ${ }^{1}$ \\ Fakultas Ekonomi, Universitas Sumatera Utara \\ isfentisadalia@gmail.com², khairaamalia@yahoo.co.id ${ }^{3}$
}

\begin{abstract}
The capital market is one of the media that provides opportunities for individual and institutional investors to invest. The development of the Indonesian capital market (LQ45 Index and IHSG Index) is closely related to the global index and macroeconomic. The purpose of this study is to examine the canonical correlation of global indices and macroeconomics with the Indonesian capital market. Samples are limited to the period 2011-2013 (36 months). Data were analyzed using canonical correlation at a significant level of 5\%. The results showed that the global index and macroeconomics had a significant relationship with the Indonesian capital market, with the canonical coefficient of perfect weights for LQ45 (1.00) and almost perfect for IHSG (0.98). This means that the Dow Jones, EIDO, exchange rates, $S B I$ interest rates have a significant positive relationship to the LQ45 Index and the JCI Index listed on the Indonesia Stock Exchange in the period 2011 to 2013. Individual Dow Jones (0.67), EIDO (0.54)) and Exchange Rate (0.37) have a positive relationship with the Indonesian capital market index (LQ45 Index and IHSG Index).
\end{abstract}

Keywords : Canonical, DowJones, EIDO, SBI, Rupiah

\section{PENDAHULUAN}

\section{Latar Belakang}

Pasar modal merupakan salah satu tempat (media) yang memberikan kesempatan berinvestasi bagi investor perorangan maupun institusional. Pasar modal merupakan sarana perusahaan untuk meningkatkan kebutuhan dana jangka panjang dengan menjual saham atau mengeluarkan obligasi kepada investor yang tertarik kepada perusahaan tersebut. IHSG dapat menjadi leading indicator economic pada suatu negara. Pergerakan indeks sangat dipengaruhi oleh ekspektasi investor atas kondisi fundamental negara maupun global. Adanya informasi baru akan berpengaruh pada ekspektasi investor yang akhirnya akan berpengaruh pada IHSG. Secara garis besar, ada tiga faktor utama yang berpengaruh terhadap pergerakan IHSG yaitu: faktor domestik, faktor asing, dan faktor aliran modal ke Indonesia (Husnan dan Pudjiastuti (2004: 14). Faktor asing merupakan salah satu implikasi dari bentuk globalisasi dan semakin terintegrasinya pasar modal di seluruh dunia sehingga terciptanya indeks global.Kondisi ini memungkinkan timbulnya pengaruh dari bursa-bursa yang maju (developed) terhadap bursa yang sedang berkembang Selama tiga periode terakhir, jumlah investor asing tetap mendominasi kepemilikan saham di Bursa Efek Indonesia. Walaupun demikian, kepemilikan investor lokal mengalami peningkatkan pada dua periode terakhir. Reaksi turunnya Indeks Dow Jones Amerika akan menurunkan IHSG dari 2.745 pada Desember 2007 juga menurun menjadi 1.1332 poin pada Januari 2009 atau menurun sebesar 48 persen.

EIDO (The iShares MSCI Indonesia ETF) yang berpusat di Amerika Serikat mempengaruhi pasar modal Indonesia. EIDO adalah indeks Mutual Fund sejenis ETF atau reksadana dibursa "NYSE (New York Stock Exchange)",yang didalamnya terdapat saham-saham Indonesia yang dipilih berdasarkan kriteria Morgan Stanley Composite Index "MSCI". EIDO memberikan pengaruh terhadap IHSG. Hal ini 
sebagaimana kejadian yang sama juga terjadi pada tahun 2010 lalu dimana kala itu Dow Jones hanya mampu menguat 1,3\% sepanjang 8-14 September 2010, tetapi EIDO mampu mencatatkan penguatan 4,5\% yang akhirnya disusul oleh IHSG pada awal perdagangan pasta libur lebaran 2010. IHSG akan lebih mengikuti pergerakan EIDO ketimbang pergerakan Dow Jones.

Indeks LQ45 dan IHSG juga mempunyai hubungan yang erat dengan faktor makro ekonomi tersebut, maka secara khusus dalam penelitian ini akan tentang nilai tukar rupiah dan SRI (Suku Bunga Indonesia). (Sukirno, 2010:397). Nilai tukar rupiah terus berfluktuasi dari tahun ke tahun. Pada awal Januari 2007 nilai tukar rupiah terhadap dollar AS berada di titik Rp 8950 dan turun menjadi Rp 12400 di pertengahan tahun 2008 karena adanya krisis ekonomi global (www.bi.go.id). Dengan berfluktuasinya nilai mata uang rupiah pada tahun 2008 disaat terjadi krisis ekonomi gobal yang membuat nilai tukar rupiah melemah dan menyebabkan kerugian bagi perusahaanperusahaan yang terdapat di LQ45 terutama perusahaan import, membuat Para investor kurang tertarik untuk menanamkan saham di bursa efek karena resiko yang terlalu tinggi dan return yang rendah. (Fahmi dan Hadi, 2009:17). Suku bunga SBI juga mengalami fluktuasidari waktu ke waktu. Tingginya nilai suku bunga SBI pada saat terjadi krisis ekonomi global membuat para investor merasa tertarik untuk berinvestasi terhadap SBI yang memiliki resiko sangat kecil dibandingkan dengan saham. Dengan demikian perlu dianalisis bagaimanakah hal hal yang mempunyai hubungan dengan pergerakan indeks pasar modal Indonesia (LQ45 dan IHSG), khususnya yang berasal dari indeks global (indeks Dow Jones dan EIDO) dan makro ekonomi (nilai tukar rupiah dan SBI).

\section{Tujuan dan Manfaat Penelitian}

Tujuan yang ingin dicapai dalam penelitian ini adalah: Untuk mengetahui hubungan indeks global (indeks Dow Jones dan EIDO) dan makro ekonomi (nilai tukar rupiah dan SBI) terhadap pergerakan indeks pasar modal Indonesia (LQ45 dan IHSG).

Penelitian ini di harapkan dapat bermanfaat sebagai:

1) Bagi penulis. Menambah wawasan dan

ilmu pengetahuan mengenai pergerakan indeks saham LQ45 dan 1HSG terutama hubungan Indeks Dow Jones, EIDO, Nilai Tukar Rupiah, dan SBI dengan pergerakan indeks saham LQ45 dan IHSG. Selain itu juga dapat memberikan informasi dan masukan yang dibutuhkan oleh pemegang saham, kreditur dan pihak-pihak terkait la innya.

2) Sebagai bahan pertimbangan bagi perusahaan, pemerintah dan pihak-pihak yang terkait dalam mengambil keputusan yang akan ditempuh sehubungan dengan pergerakan indeks saham LQ45 dan IHSG di BEI.

3) Bagi peneliti lain, sebagai bahan referensi dan informasi bagi yang ingin melakukan penelitian selanjutnya.

\section{KAJIAN LITERATUR}

\section{Pengertian Pasar Modal}

Pengertian pasar modal menurut Fahmi dan Hadi (2009:41) adalah tempat berbagai pihak, khususnya perusahaan menjual saham (stock) dan obligasi (bond), dengan tujuan dari hasil penjualan tersebut nantinya akan dipergunakan sebagai tambahan dana atau memperkuat modal perusahaan.. Sedangkan menurut Keppres No. 60 tahun 1988, "pasar modal adalah bursa yang merupakan sarana untuk mempertemukan penawar dan peminta dana jangka panjang dalam bentuk efek, sebagaimanan dimaksud dalam undang- undang no. 15 tahun 1952 tentang bursa". Jadi pasar modal merupakan salah satu bentuk kegiatan dari lembaga keuangan non bank sebagai sarana untuk memperluas sumber-sumber pembiaya-an perusahaan. Aktivitas ini terutama ditujukan bagi perusahaan yang membutuhkan dana dalam jumlah 
besar dan penggunaannya diperlukan untuk jangka panjang yang seringkali tidak dapat dipenuhi oleh lembaga perbankan, sehingga sumber dana alternatif dapat dicari melalui pasar modal.

Sebagai sumber dana eksternal, pasar modal mempunyai pengertian abstrak yang mempertemukan dua kelompok yang saling berhadapan tetapi kepentingannya untuk saling mengisi, yakni calon pemodal di satu pihak dan emiten yang membutuhkan dana jangka menengah atau panjang di pihak lain, atau dengan kata lain pasar modal adalah tempat (dalam artian abstrak) bertemunya penawaran dan permintaan dana jangka menengah dan jangka panjang. Oleh karena itu, fungsi pasar modal adalah mengalokasikan secara efisien anus dana dari unit ekonomi yang mempunyai surplus tabungan (saving surplus unit) kepada unit ekonomi yang mempunyai defisit tabungan.

Berdasarkan jenis transaksi, aktivitas pasar modal dapat dibedakan menjadi 3 bagian, yaitu: Pertama pasar perdana. Pasar perdana adalah penjualan perdana efeklsertifikat atau penjualan yang dilakukan sesaat sebelum perdagangan di pasar sekunder. Pada saat ini efeklsertifikat diperdagangkan dengan harga emisi dan bagi perusahaan yang menerbitkan sahamnya di pasar ini akan memperoleh dana dengan menjual sekuritas seperti saham dan obligasi. Kedua pasar sekunder. Pasar sekunder adalah penjualan efek/sertifikat setelah pasar perdana berakhir. Pada pasar ini efek yang diperdagangkan dengan harga kurs. Ketiga bursa paralel (Pasar Luar Bursa). Bursa Paralel merupakan suatu sistem perdagangan efek yang terorganisir di luar bursa efek Jakarta, dengan bentuk pasar sekunfer, diatur dan diselenggarakan oleh Perserikatan Perdagangan Uang dan Efek-efek (PPUE), diawasi dan dibina oleh Badan Pelaksana Pasar Modal (Bapepam).

\section{Produk atau Instrumen Pasar Modal}

Produk atau instrumen pasar modal terdiri dart beberapa macam. Di antaranya sebagaimana yang dinyatakan Hariyani dan Pumomo (2010), yaitu: Saham, obligasi, derivatif, kontyrak opsi saham, kontrak berjangka indeks saham, waran, right/HMETD. Reksadana, grimier ETF LQ45, dana investasi real estate, surat utang negara, indeks harga saham dan obligasi, dan efek beragun aset. Sedangkan Syamsul (2011) menyebutkan beberapa produk atau instrumen pasar modal yang disebut efek, yaitu surat berharga yang berupa (1) saham, (2) obligasi, (3) bukti right, (4) bukti waran, dan (5) produk turunan atau biasa disebut derivative. Dari berbagai macam produk atau instrumen pasar modal, maka yang sudah terdapat di Bursa Efek Indonesia (BEI) adalah: Saham (stock); Surat Utang (Obligasi Korporasi; Surat Utang Negara; Sukuk Korporasi; $\quad$ Surat Berharga Syariah NegaraISBSN atau Sukuk Negara; Efek Beragun Aset (EBA); dan Reksa dana (Reksa Dana Pasar Uang, Reksa Dana Pendapatan Tetap, Reksa Dana Saham dan Reksa Dana Campuran); Derivatif keuangan (saham, obligasi, indeks saham, indeks obligasi, mata uang, tingkat suku bunga dan instrumeninstrumen keuangan lainnya). Beberapa Jenis Produk Turunan yang diperdagangkan di BEI adalah Kontrak Opsi Sahara (KOS) dan Kontrak Berjangka Indeks Efek (KBIE), seperti: LQ45 Futures, Mini LQ45 Futures, LQ45 Futures Periodik, Mini LQ45 Futures Period ik, Japan (JP) Futures,

\section{Indeks Indonesia}

\section{Indeks Harga Saham Gabungan}

Indek Harga Saham Gabungan (MSG) sebenarnya merupakan angka indek harga saham yang sudah disusun dan dihitung sehingga menghasilkan trend, di mans angka indek adalah angka yang diolah sedemikian rupa sehingga dapat digunakan membandingkan kejadian yang dapat berupa perubahan harga saham dart waktu ke waktu. Dalam perhitungan angka indek ini digunakan waktu dasar (base period) dan waktu yang sedang berjalan (given/parent period).

Adapun jenis-jenis Indek Harga Saham Gabungan adalah:

1. Seluruh saham, adalah suatu nilai yang digunakan untuk mengukur kinerja gabungan seluruh saham yang tercatat di suatu bursa efek. 
2. Kelompok saham, adalah suatu nilai yang digunakan untuk mengukur kinerja kelompok saham yang tercatat di suatu bursa efek.

a. Indek LQ45 adalah indek atas 45 emiten yang tercatat di Bursa Efek Jakarta, dengan tolak ukur likuiditas dan nilai kapitalisasi pasar.

b. Indek Jll (Jakarta Islamic Index) indek yang digunakan sebagai tolak ukur (bencmark) kinerja suatu investasi pada saham dengan basis syariah.

3. Jenis usaha (sektoral) adalah suatu nilai untuk mengukur kinerja kelompok saham yang diklasifikasikan ke dalam 9 sektor yaitu sektor pertanian, pertambangan, industri dasar dan kimia, industri barang konsumsi, properti dan real estate, transportasi dan infrastruktur, Keuangan, perdagangan, jasa dan investasi

Secara umum pergerakan harga saham dipengaruhi oleh faktor internal (lingkungan mikro) dan faktor eksternal (lingkungan makro). Di antara lingkungan mikro yang mempengaruhi volatilitas harga saham antara lain: Pengumuman tentang pemasaran, produksi,

penjualan; Pengumuman pendanaan; Pengumuman badan direksi manajemen; Pengumuman penggabungan pengambilalihan diversifikas; Pengumuman investasi; Pengumuman ketenagakerjaan; dan Pengumuman laporan keuangan perusahaan. Sedangkan lingkungan ekonomi makro yang mempengaruhi volatilitas harga saham antara

lain: Pengumuman dart pernerintah; Pengumuman hukum (legal announcements); Pengumuman industri sekuritas; Gejolak sosial politik dalam negeri dan fluktuasi nilai tukar; dan berbagai issue baik dart dalam dan luar negeri.

Indek LQ45 adalah indek atas 45 emiten yang tercatat di Bursa Efek Jakarta, dengan tolak ukur likuiditas dan nilai kapitalisasi pasar. Keterkaitan pasar modal Indonesia dengan pasar modal luar negeri dimulai setelah diperbolehkan-nya Parainvestor untuk Menguasai saham saham yang tercatat di Bursa Efek Jakarta. Investasi portofolio asing berperan sangat penting di pasar modal manapun (Mobius, 1998). Walaupun peranan investor domestik makin meningkat akan tetapi terdapat kebiasaan dari investor domestik untuk melakukan strategi mengekor pada investor asing atau setidaknya investor domestik menggunakan perilaku investor asing sebagai acuan (Cahyono, 2000). Sewaktu investor asing melapas sahamnya, investor domestikpun ikut ikutan, akibatnya indeks dapat turun semakin tajam.

Dow Jones Industrial Average (DJIA) adalah. salah satu indek pasar saham yang didirikan oleh editor The Wall Street Journal dan pendiri Dow Jones \& Company Charles Dow. Dow membuat indek ini sebagai suatu cara untuk mengukur performs komponen industri di pasar saham Amerika. Saat ini DJIA merupakan indek pasar AS tertua yang masih berjalan. Sekarang, bursa saham ini terdiri dari 30 perusahaan terbesar di Amerika Serikat yang sudah secara luas go public, yaitu: 3M (konglomerat, manufaktur), Alcoa (aluminium), Altria Group American International Group American Express, Boeing, Caterpillar, Citigroup, Coca-Cola, DuPont, Exxon Mobil, General Electric, General Motors, Hewlett-Packard, Home Depot, Honeywell International, Intel, International Business Machines, J.P. Morgan Chase, Johnson \& Johnson, McDonald's, Merck \& Co, Microsoft, Pfizer, Procter and Gamble, SBC Communications, United Technologies, Verizon, Wal-Mart, Walt Disney Company.

Indeks Dow Jones merupakan rata-rata indek saham terbesar di dunia yang dapat mempengaruhi hampir seluruh indek saham dunia termasuk 1HSG. Pengaruh DJIA terhadap IHSG diperkirakan positif dalam arti kenaikan DJIA akan mengakibatkan naiknya IHSG, karena adanya sentimen positif dari para investor terhadap kondisi ekonomi dunia.

EIDO (The iShares MSCI Indonesia ETF) yang berpusat di Amerika Serikat Indeks Mutual Fund sejenis ETF atau reksadana dibursa "NYSE (New York Stock Exchange)", yang di dalamnya terdapat sahamsaham Indonesia yang dipilih berdasarkan kriteria dari Morgan Stanley Composite Index "MSCI" (www. Republika.co.id, Jakarta). Di antara perusahaan yang tercatat di EIDO adalah: Astra International tbk. Bank Central Asia tbk. Telekomunikasi tbk. Bank Rakyat Indonesia (persero) tbk. bank Mandiri tbk. Perusahaan Gas Negara tbk. Unilever Indonesia, tbk Semen Gresik (persero) tbk. Bank Negara 
Indonesia, Persero Kalbe Farmat bk, PT United Tractors tbk. Indofood Sukses Makmur, tbk Indocement Tunggal Prakarsa, dan Charoen Pokphand Indonesia, tbk. Bagi investor Dunia yang tidak dapat berinvestasi di pasar saham Indonesia mereka dapat langsung berinvestasi seperti reksadana dengan cara membeli EIDO. Secara tidak langsung IHSG seolah dual listing dibursa NYSE. Pergerakannya di bursa NYSE juga memiliki sentimen, balk positif ataupun negatif bagi pergerakan IHSG keesokan harinya, Contohnya: Pada perdagangan tanggal 27 january 2012 indeks EIDO berhasil ditutup menguat $+0,06 \%$ menjadi 31,0100.

\section{Ekonomi makro}

Ekonomi makro sebagai ilmu yang mempelajari tentang pokok-pokok ekonomi, baik dalam jangka pendek maupun jangka panjang yang meliputi stabilitas dan pertumbuhan ekonomi suatu negara (Budiono 2001). (Sadono Sukirno 2010) Ekonomi makro adalah cabang ekonomi yang mempelajari kegiatan ekonomi komprehensif secara komprehensif terhadap berbagai masalah pertumbuhan ekonomi. Yang mana masalah tersebut meliputi: pengangguran, inflasi, neraca perdagangan dan pembayaran, aktivitas ekonomi yang tidak stabil. Tidak ada teori yang membantah adanya hubungan antara pasar saham dengan keadaaan makro ekonomi. Menurut Chen et all (dalam Sitinjak dan Widuri, 2003), perubahan harga saham biasanya merupakakan respon dan kekuatan eksternal. Selain itu memang ada kebijakan moneter (berkaitan dengan makro ekonomi) yang mempengaruhi pasar modal dan pasar uang secara bersama sama.

Nilai tukar (kurs) adalah sesuatu nilai yang menunjukkan harga atau nilai mata uang sesuatu negara dinyatakan dal= nilai mata uang negara lain. Nilai tukar (kurs) dapat juga didefinisikan sebagai jumlah uang domestik yang dibutuhkan, yaitu banyaknya rupiah yang dibutuhkan untuk memperoleh satu unit mata uang asing (Sukimo, 2010:397) Nilai tukar Rupiah atau disebut juga kurs Rupiah adalah perbandingan nilai atau harga mata uang Rupiah dengan mata uang lain. Perdagangan antar negara di mans masing-masing negara mempunyai alat tukarnya sendiri mengharuskan adanya angka perbandingan nilai suatu mata uang dengan mata uang lainnya, yang disebut kurs valuta asing atau kurs (Salvatore, 2008). Nilai tukar terbagi atas nilai tukar nominal dan nilai tukar riil. Nilai tukar nominal (nominal exchange rate) adalah nilai yang digunakan seseorang saat menukar mata uang suatu negara dengan mata uang negara lain. Sedangkan nilai riil (real exchange rate) adalah nilai yang digunakan seseorang saat menukar barang dan jasa dari suatu negara dengan barang dan jasa dari negara lain (Mankiw, 2006).Nilai tukar yang melonjak-lonjak secara drastic tak terkendali akan menyebabkan kesulitan pada dunia usaha daiam merencanakan usahanya terutama bagi mereka yang mendatangkan bahan baku dan luar negeri atau menjual barangnya ke pasar ekspor oleh karena itu pengelolaan nilai mata uang yang relatif stabil menjadi salah satu faktor moneter yang mendukung perekonomian secara makro (Pohan, 2008).

Kurs inilah sebagai salah satu indikator yang mempengaruhi aktivitas di pasar saham maupun pasar uang karena investor cenderung akan berhati-hati untuk melakukan investasi. Menurunnya kurs Rupiah terhadap mata uang asing khususnya Dolar AS memiliki pengaruh negatif terhadap ekonomi dan pasar modal (Sitinjak dan Kurniasari, 2003). Turunnya kurs menurunkan kemampuan nilai tukar Rupiah terhadap mata uang asing salah satu dampaknya terhadap impor.

Sertifikat Bank Indonesia atau SBI menurut Siamat (2005:455) pada dasarnya adalah surat berharga atas unjuk dalam rupiah yang diterbitkan oleh Bank Indonesia sebagai pengakuan utang berjangka waktu pendek dan diperjualbelikan dengan diskonto. Salah satu instrumen pasar uang yang digunakan oleh Bank Indonesia untuk mengendalikan likuiditas perekonomian adalah Sertifikat Bank Indonesia atau SBI. SBI adalah instrumen keuangan jangka pendek yang dijadikan tolak ukur oleh bank-bank pemerintah, swasta nasional dan swasta asing dalam menentukan tingkat suku bunga tabungan, deposito dan pinjaman kepada masing-masing nasabahnya. Dalam kondisi normal fungsi utama SBI adalah menjaga uang yang beredar berada dalam jumlah yang optimal. Namun sejak krisis 
moneter meianda Indonesia tahun 1997, SBI juga digunakan oleh Bank Sentra! untuk mencegah meningkatnya permintaan dana oleh masyarakat dan kalangan pengusaha swasta nasional untuk keperluan transaksi dan berjaga-jaga. Pada kondisi tersebut, meningkatnya permintaan uang oleh masyarakat dan kalangan pengusaha nasional tidak sepenuhnya digunakan untuk keperluan dimaksud, namun digunakan untuk berspekulasi membeli dollar guns memperoleh keuntungan yang spekulatif SBI pada dasarnya adalah merupakan instrumen jangka pendek yang bebas risiko.

\section{Kerangka Konseptual}

Berdasarkan latar belakang masalah yang telah di uraikan, maka kerangka pemikiran yang dapat digambarkan sebagai berikut:

Gambar set variabel bebas (independent) dan set variabel terikat (dependent)

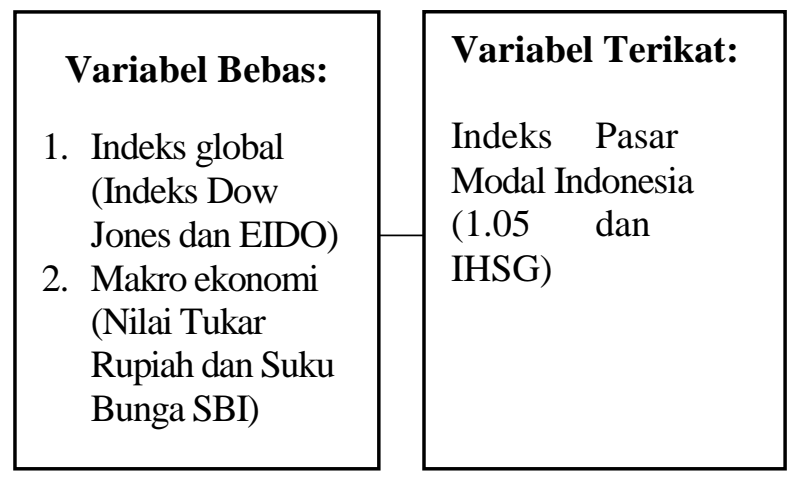

\section{Gambar 1. Set \\ Variabel Penelitian}

\section{Hipotesis}

Hipotesis penelitian ini adalah: Indeks global (Indeks Dow Jones dan EIDO) dan ekonomi makro (nilai tukar rupiah dan suku bunga SBI) secara serempak mempunyai hubungan yang signifikan dengan indeks pasar modal Indonesia (LQ45 dan IHSG).

\section{METODE}

Penelitian ini menggunakan data yang terdapat di IDX Fact Book sebagai populasi penelitian. Sedangkan sampel penelitiannya dibatasi pada periode 2011 sampai dengan 2013 yang terdiri dari 36 bulan. Jenis data penelitian ini adalah sekunder yang merupakan publikasi Bursa Efek Indonesia, buku buku referensi, jurnal, hasil penelitian, dan data di internet yang berkaitan dengan topik bahasan penelitian. Analisis deskriptif merupakan pendeskripsian variabel data penelitian melalui pengumpulan, klasifikasi, dan dinterpretasikan secara objektif, sehingga memberikan informasi dan gambaran mengenai topik yang dibahas.

Untuk pengujian hipotesis dilakukan dengan korelasi kanonik yang bertujuan secara dasar sama dengan korelasi sederhana atau berganda, yakni ingin mengetahui apakah ada hubungan (asosiasi) antara dua variabel ataukah tidak? Namun berbeda dengan korelasi sederhana, pada korelasi kanonik jumlah variabel dependen dan variabel independen lebih dari satu, sehingga alat analisis korelasi kanonik bisa digolongkan pada multivariat. (Santoso, 2010: 259).

Pengujian korelasi kanonik dilakukan dengan bantuan SPSS (Statistical Packade for Social Scienes dengan menggunakan tingkat kepercayaan (convidence interval) sebesar $95 \%$ dan tingkat toleransi kesalahan a 5\%. Bentuk pengujiannya sebagai berikut: 
1. Ho : bi $=b 2=b 3=b 4=0$, artinya secara serempak Indeks Dow Jones, Indeks EIDO, Nilai Tukar Rupiah, dan Suku Bunga SBI mempunyai hubungan yang tidak signifikan dengan variabel terikat yaitu LQ45 dan IHSG.

2. $\mathrm{H}_{\mathrm{a}}$ : minimal satu b,0, artinya secara serempak Indeks Dow Jones, Indeks EIDO, Nilai Tukar Rupiah, dan Suku Bunga SBI mempunyai hubungan yang signifikan dengan variabel terikat yaitu LQ45 dan IHSG.

Uji ini dilakukan dengan membandingkan $\mathrm{F}_{\text {Hitling }}$ dengan $\mathrm{F}_{\text {tabei }}$ dengan ketentuan sebagai berikut: Ho diterima (Ha ditolak) jika $F_{\text {Hitung }}>$ Ftabel pada $a=5 \%$ dan Ho ditolak $\left(\mathrm{H}_{\mathrm{a}}\right.$ diterima $)$ jika $\mathrm{F}_{\text {Hitung }}<$ Ftabel pada $\mathrm{a}=5 \%$.

Uji asumsi korelasi kanonikal adalah sebagaimana yang dikemukakan oleh Santoso (2010: 259), yaitu syarat-syaratnya adalah: (1) Adanya hubungan yang bersifat linier antar dua variabel. (2) Perlunya Multivariate Normality untuk menguji signifikansi setiap fungsi kanonik; dan (3) Tidak ada Multikolinieritas antar anggota kelompok variabel, balk variabel dependen maupun variabel independen. Dengan demikian akan digunakan 3 (tiga) uji asumsi korelasi kanonikal, yaitu uji linieritas, uji normalitas, dan uji multikolinieritas.

\section{HASIL DAN DISKUSI}

\section{Pembahasan}

Data untuk masing-masing variabel penelitian ini adalah sebagai berikut: Perkembangan Indeks Dow Jones yang tertinggi pada tahun 2013 sebesar 2716,08 poin dan yang terendah pada tahun 2012 sebesar 1043.68 pain. Pada awal tahun 2011 sampai akhir tahun 2013 mengalami peningkatan yang cukup baik. Naiknya Indeks Dow Jones disebabkan adanya peningkatan terhadap fundamental ekonomi makro Amerika Serikat dan dun ia sehingga dapat meningkatkan indikator ekonomi Amerika Serikat seperti naiknya PDB, turunnya pengangguran, naiknya kepercayaan investor terhadap perusahaan dan neraca pembayaran yang terus surplus. Perkembangan Indeks EIDO secara umum dalam tiga tahun terakhir ini adalah relatif stabil dengan rata rata 28 dan 29 pain. Terjadi penurunan 1 pain pada tahun 2013, tetapi pada tahun ini juga mencatat poin tertinggi 35,57 pada April 2013 dan juga mengalami poin terendah yaitu 22.84 pada Desember 2013. Fluktuasinya lebih tajam pada 2013, akhirnya menuju poin terendah yaitu pada level 22. Kestabilan Indeks EIDO secara umum pada tahun 2011 sampai dengan 2013 adalah disebabkan oleh mem bai karya fundamental ekonomi makro Amerika Serikat dan dunia, serta Indonesia, sehingga meningkatnya tingkat kepercayaan investor di Amerika Serikat.

Perkembangan nilai tukar rupiah terus mengalami kenaikan pada setiap tahunnya, yaitu tahun 2011 pada kisaran delapan ribuan, maka pada tahun 2012 pada kisaran sembilan ribuan, serta akhirnya pada tahun 2013 telah menyentuh level dua belas ribuan. Hal ini menunjukkan lemahnya fundamental ekonomi Indonesia, khususnya menuju pemilu 2014. Perkembangan Suku Bunga SBI secara umum tahun 2011 hingga 2013 mengalami penurunan, dari rata rata 0,54306 pada tahun 2011 menjadi rata rata 0,36813 pada tahun 2012, dan menaik lagi menjadi rata rata 0,48271 pada tahun 2013, namun tetap lebih rendah dibanding rata rata tahun 2011. Hal ini menunjukkan lemahnya fundamental ekonomi Indonesia, khususnya menuju pemilu 2014. Perkembangan Indeks LQ45 secara umum dalam tiga tahun terakhir ini secara rata rata menunjukkan peningkatan, yaitu pada tahun 2011 pada 663.22 poin, tahun 2012 meningkat menjadi 706.86 poin, dan pada tahun 2013 meningkat lagi menjadi 773.34 poin. Tetapi pada tahun 2013 terjadi fluktuasi yang tajam, yaitu poin tertinggi adalah 857,12 dan poin terendah adalah 701,07 poin. Hal ini disebabkan semakin membaiknya kinerja perusahaan yang tergabung dalam LQ45 dan juga didukung oleh keadaan perekonomian Amerika Serikat dan dunia yang re latif stabil. Perkembangan IHSG dari tahun 2011 sampai dengan 2013 telah mengalami peningkatan yang signifikan. Pada tahun 2012 telah mengalami kenaikan menjadi 4118.828 poin dan pada tahun 2013 naik lagi menjadi 4607,463 poin. Hal ini disebabkan semakin membaiknya kinerja perusahaan yang 
tergabung dalam IHSG den juga didukung oleh keadaan perekonomian Amerika Serikat dan dunia yang relatif stabil.

\section{Pengujian Asumsi Korelasi Kanonikal Uji Linieritas}

Rangkuman hasil pengujian tersebut adalah: Kedelapan pasangan variabel dependen dengan variabel independen telah diperoleh hasil signifikansinya: $\mathrm{LQ} 45 * \mathrm{IDJ}=0,363 ; \mathrm{LQ} 45 * \mathrm{EIDO}=0,385 ; \mathrm{LQ} 45^{*} \mathrm{SBI}=$ 0,472; LQ45* NTR = 0,067; IHSG*IDJ =0,349; IHSG*EIDO =0,368; IHSG * SBI = 0,409; dan IHSG* NTR $=0,065$. Dengan demikian dapatlah dinyatakan bahwa kedelapan pasangan variabel tersebut adalah linier, karena hasil hitungan signifikansi lebih besar dari 0,05 . Hal ini menunjukkan bahwa syarat uji linieritas korelasi kanonikal telah terpenuhi.

\section{Uji Normalitas Data}

Hasil perhitungan uji normalitas dengan menggunakan Kolmogorov-Smirnov test adalah keenam variabel tersebut adalah normal secara signifikan, karena nilai signifikansi keenam variabel tersebut (IDJ 0,909, EIDO 0,434, NTR 0,122, SBI 0,206, LQ45 0,401, dan IHSG 0,328) lebih besar dari tingkat kekeliruan $5 \%(0,05)$.

\section{Uji Multikolinearitas}

Hasil uji multikolinieritas: Nilai Tolerance variabel IDJ adalah 0,143, EIDO adalah 0,617, nilai tukar rupiah adalah 0,121 , dan nilai SBI adalah 0,858 pada model 1 dan 2. Nilai tolerance untuk semua variabel independen adalah lebih besar dari 0,10 , sehingga data variabel tersebut bebas dari masalah multikolinieritas. Sedangkan Nilai VIF variabel IDJ adalah 7,003, EIDO adalah 1,621, nilai tukar rupiah adalah 8,259, dan nilai SBI adalah 1,165 pada model 1 dan 2. Nilai VIF untuk semua variabel independen adalah lebih besar dari 10,00, sehingga bebas dari masalah multikolinieritas. Dengan demikian dapat disimpulkan bahwa variabel independen penelitian ini, balk pada model 1 dan 2 model bebas dari masalah multikolinieritas, karena semua nilai tolerance lebih besar dari 0,10 dan nilai VIF lebih kecil dari 10,00.

\section{Diskusi}

\section{Pengujian secara individual}

Banyaknya root adalah • berdasarkan jumlah variabel $Y$. Root dalam korelasi kanonikal ini ada dua, root 1 adalah hubungan variabel independen, yaitu Indeks Dow Jones $\left(\mathrm{X}_{1}\right)$, EIDO $\left(\mathrm{X}_{2}\right)$, Nilai Tukar Rupiah (XO, dan Suku Bunga SBI $\left(\mathrm{X}_{4}\right)$ dengan variabel dependen, yaitu LQ45 $\left(\mathrm{Y}_{1}\right)$, dan root 2 adalah hubungan variabel independen, yaitu Indeks Dow Jones $\left(\mathrm{X}_{1}\right)$, EIDO $\left(\mathrm{X}_{2}\right)$, Nilai Tukar Rupiah $\left(\mathrm{X}_{3}\right)$, dan Suku Bunga SBI ( $\left.\mathrm{X}_{4}\right)$ dengan variabel dependen, yaitu IHSG $\left(\mathrm{Y}_{2}\right)$. Untuk membentuk perhitungan korelasi kanonikal terhadap kedua root tersebut adalah 2 (dua) hal penting yang perlu dihitung terlebih

yaitu Eigenvalues dan Canonical Correlations. Pertama adalah eigenvalue atau nilai eigen, yaitu ketika penggalian akar kanonik, kita menghitung nilai eigen. Ini dapat diartikan sebagai proporsi varians dicatat dengan korelasi antara variates kanonik masing masing. Perhatikan bahwa proporsi ini dihitung relatif terhadap varians dari variates kanonik, yaitu dari nilai jumlah tertimbang dari dua set variabel, yaitu root 1 dan root 2. (www.sotsoft. corn/Textbook/ Canoni-calAnalysis). Sedangkan Canonical Correlations adalah besarnya korelasi kanonik antara variabel variabel dependen dengan variabel independen pada root 1 dan root 2. Hasil perhitungan eigenvalue dan canonical correlations untuk root 1 dan root 2 adalah: eigenvalue pada root 1 adalah 14,79360 dan eigenvalue pada root 2 adalah 3,73050. Jadi eigenvalue.pada root 1 adalah lebih besar dari eigenvalue pada root 2. Sedangkan canonical correlations untuk root 1 adalah 0,96782 dan canonical correlations untuk root 2 adalah 0,88804 . Jadi 
canonical correlations pada root 1 adalah lebih besar dari eigenvalue pada root 2 . Nilai canonical correlations kedua root ini akan diuji signifikansinya sebagai berikut:

Tabel 1. Perhitungan Signifikansi Korelasi Kanonikal

\begin{tabular}{|lcl|}
\hline & \multicolumn{2}{c|}{ Dimension Reduction Analysis } \\
\cline { 2 - 3 } Roots & Wilks L. & F \\
1 TO 2 & 0.01338 & 57.32749 \\
2 TO 2 & 0.21139 & 38.54937 \\
\hline
\end{tabular}

Berdasarkan tabel 1 menunjukkan bahwa signifikansi korelasi kanonikal root 1 adalah 0,000 dan korelasi kanonikal root 2 adalah 0,000 . Nilai signifikansi root 1 dan root 2 yang masing-masing $0,000<$ 0,05 , yang berarti signifikan secara individual. Oleh karena itu root 1 dan root 2 dapat diproses lebih lanjut.

\section{Pengujian secara kelompok}

Perhitungan secara kelompok atau secara bersama-sama. Dengan menagunakan ernpat prosedur dari Pillais, Hotellings, Wilks, dan Roys, maka hasilnya adalah semuanya signifikan, karena < 0,05. Dengan demikian jika digabung secara bersama-sama, kanonikal root 1 dan kanonikal root 2 dapat diproses lebih lanjut. Dari hasil pengujian individu dan bersama (kolektif) terdapat perbedaan korelasi kanonik yaitu terlihat pada tabei 4.20, dengan angka korelasi kanonik root $I=0.96782$ dan korelasi kanonik root $2=0.88804$. Oleh karena root 1 memiliki angka korelasi kanonik yang lebih tinggi dan signifikan baik secara individu maupun kolektif, maka analisis selanjutnya hanya menitikberatkan pada root 1 dengan mengabaikan root 2 .

\section{Interpretasi kanonikal variates}

Analisis ini merupakan kelanjutan dari pengujian sebelumnya yang menetapkan kanonik root 1. Oleh karena itu dalam analisis ini hanya memperhatikan kanonikal root I. Dalam penelitian ini ada dua kanonik variates yaitu dependen kanonik variates yang berisi LQ45 dan IHSG dan kanonik independen variates yang berisi Indeks Dow Jones, EIDO, Nilai Tukar Rupiah, dan Suku Bunga Indonesia. Analisis ini berfungsi untuk mengetahui apakah semua variabel independen dalam kanonik variates berhubungan dengan dependen variates, yang diukur dengan besaran korelasi masingmasing independen variabel dengan variatnya. Pengukuran dilakukan dengan dua cara yaitu kanonikal Weights dan kanonikal Loadings.

1). Kanonikal Weights

Kanonikal weights adalah menunjukkan besarnya korelasi dalam perhitungan korelasi kanonikal. Hubungan variabel independen LQ45 ( $\left.\mathrm{Y}_{1}\right)$ dan IHSG (Y2) dengan variabel dependennya (Indeks Dow Jones, EIDO, Nilai Tukar Rupiah, dan Suku Bunga Indonesia) pada fungsi 1 dan fungsi 2 diabaikan. Koefisien kanonikal standar untuk variabel LQ45 adalah 1,00000 dan untuk variabel IHSG adalah 0,97999. Hal ini menunjukkan bahwa Koefisien kanonikal standar untuk variabel LQ45 $\left(\mathrm{Y}_{1}\right)$ adalah sempurna, karena nilainya adalah 1,0. Selanjutnya adalah menghitung koefisien kanonikal kasar untuk kovariats (Indeks Dow Jones, EIDO, Nilai Tukar Rupiah, dan Suku Bunga Indonesia) terhadap LQ45 dan IHSG.: Root yang akan dianalisis adalah fungsi 1 yang berasal dari runt 1 dan fungsi 2 diabaikan. Koefisien kanonikal kasar covariat terhadap variabel LQ45 adalah: IDJ 0.00028, EIDO 0.28205, NTR 0.00067, dan SBI -1.14507. Jadi dapat dipahami bahwa secara Koefisien kanonikal kasar covariat IDJ, EIDO, NTR mempunyai nilai yang searalt dengan tanda positif, maksudnya kalau kovariatnya naik, maka LQ45 juga naik. Sc bal ikriya N TR mempunyai nilai yang berlawanan arah dengan tanda negatif, maksudnya kalau kovariatnya naik, maka LQ45 juga turun.

Dengan hanya memperhatikan root 1 , terlihat deretan angka korelasi LQ45 ( $\left.\mathrm{Y}_{1}\right)$ dengan variabel covariatnya. Untuk variabel dependen ada satu angka korelasi yang tinggi yaitu 0,92946 
(EIDO) dan yang terendah adalah nilai SBI $(0,11083)$. Secara umum keseluruhan covariat LQ45 adalah positif. Selain dengan kanonikal weights, interpretasi dilakukan dengan melihat besaran kanonikal loadings. Korelasi ini juga disebut faktor loadings kanonik. Logika di sini adalah bahwa variabel yang sangat berkorelasi dengan variate kanonik memiliki lebih banyak kesamaan dengan itu.Oleh karena itu, kits hares mempertimbangkan mereka lebih berat ketika menurunkan interpretasi bermakna dari variate kanonik masing. Metode ini menafsirkan variates kanonik identik dengan cara di mana faktor diinterpretasikan dalam analisis faktor.

Hasil perhitungan kanonikal loading untuk dependen variat adalah hubungan variabel independen LQ45 (Y1) dan IHSG ( $\left.\mathrm{Y}_{2}\right)$ dengan variabel dependennya (Indeks Dow Jones, EIDO, Nilai Tukar Rupiah, dan Suku Bunga Indonesia) pada fungsi 1 dan fungsi 2 diabaikan. Koefisien kanonikal standar untuk variabel LQ45 adalah 0,98868 dan untuk variabel IHSG adalah 0,01155. Hal ini menunjukkan bahwa Koefisien kanonikal loadings untuk variabel LQ45 ( $\left.\mathrm{Y}_{1}\right)$ adalah sangat tinggi, karena nilainya mendekati nilai 1,0. Hasil perhitungan kanonikal loadings dengan hanya melihat root I maka terlihat deretan angka korelasi loading masing-masing variabel dengan variabel variatnya. Sedangkan pada variabel independen atau covariat ada tiga kanonikal loadings yang positif, yaitu IDJ 0,66809, EIDO 0,53528, dan NTR 0,36539, sedangkan SBI negatif, yaitu -0,28827. Dengan demikian covariat yang positif memberikan pengaruh yang searah, dan covariat yang negatif memberikan pengaruh yang berlawanan arah.

\section{KESIMPULAN}

1. Dua variabel dependen dan empat variabel independen memiliki hubungan yang signifikan. Dengan perkataan lain terdapat hubungan antara Indeks Dow Jones, EIDO, Nilai Tukar Rupiah, dam Suku Bunga Indonesia dengan LQ45 dan IHSG, jika dilakukan pengujian secara kelompok.

2. Dari empat variabel independen, ada dua variabel yang memiliki hubungan yang yang sangat tinggi dan positif, yaitu Indeks Dow Jones dan Nilai Tukar Rupiah, dan satu variabel yang memiliki hubungan yang sangat tinggi dan negatif, yaitu Suku Bunga Indonesia. Dengan demikian dapat diartikan: Bila Indeks Dow Jones dan Nilai Tukar Rupiah tinggi, maka Indeks LQ45 dan IHSG akan tinggi, atau sebaliknya bila Indeks Dow Jones dan Nilai Tukar Rupiah rendah, maka Indeks LQ45 dan IHSG akan rendah. Sebaliknya, bila Suku Bunga Indonesia tinggi, maka Indeks LQ45 dan IHSG akan rendah, atau sebaliknya bila Suku Bunga Indonesia rendah, maka Indeks LQ45 dan IHSG akan tinggi.

3. Indeks Dow Jones dan Nilai Tukar Rupiah mempunyai hubungan yang sangat tinggi dan positif dengan Indeks LQ45 dan Indeks IHSG. Hal ini dapat dipahami karena Indeks Dow Jones merupakan indeks pasar modal di Amerika Serikat yang sangat berpengaruh di seluruh dunia, termasuk di Indonesia, sesuai dengan kuatnya posisi perekonomian Amerika Serikat. Keadaan ini juga dialami oleh Indeks EIDO, karena semakin banyaknya investor yang membeli saham EIDO yang merupakan gabungan perusahaan Indonesia yang listing di New York, berarti akan memberikan sumbangan positif terhadap indeks LQ45 dan Indeks IHSG, karena berarti semakin banyak investor yang membeli saham perusahaan Indonesia, sehingga semakin memperbanyak modal yang masuk ke Indonesia. Demikian jtiga halnya dengan Nilai Tukar Rupiah sebagai mata uang resmi Indonesia mempunyai hubungan yang sangat tinggi dan positif terhadap Indeks LQ45 dan Indeks IHSG. Keadaan nilai tukar rupiah yang kuat, khususnya terhadap dolar Amerika Serikat akan memberikan pengaruh terhadap penguatan Indeks LQ45 dan Indeks IHSG, karena mata uang ini dipakai dan dipergunakan dalam hampir seluruh transaksi keuangan di Indonesia. Sebaliknya suku bunga SBI mempunyai hubungan tinggi yang negatif, karena bila suku bunga SBI tinggi, inaka investor menjadi tertekan untuk berinvestasi. Sedangkan suku bunga SBI yang rendah akan menyebabkan investor lebih bergairah dalam berinvestasi. Hal ini disebabkan SBI adalah instrumen 
keuangan jangka pendek yang dijadikan tolak ukur oleh bank-bank pemerintah, swasta nasional dan swasta asing dalam menentukan tingkat suku bunga tabungan, deposito dan pinjaman kepada masingmasing nasabahnya.

4. Beberapa hasil penelitian terdahulu yang relevan dengan variabel penelitian ini antara lain adalah:

Penelitian Nugroho (2013) yang menyimpulkan bahwa suku bunga SBI berpengaruh positif terhadap Indeks LQ45. Hal ini berlawanan dengan hasil penelitian Rahayu (2602) yang menyimpulkan bahwa Suku Bunga SBI berpengaruh negatif dan signifikan terhadap Indeks LQ45.

Penelitian Murni (2010) menyim-pulkan bahwa Suku Bunga SBI berpengaruh negatif terhadap IHSG, yaitu bila variabel tingkat bunga SBI meningkat, maka nilai IHSG akan turun, sebaliknya bila suku bunga SBI meningkat, maka akan menurunkan indeks IHSG.

Penelitian Mansyur (2005) yang menyimpulkan: Indek Bursa Global berpengaruh signifikan terhadap Indek Harga Saham Gabungan (IHSG) Pada Bursa Efek Jakarta (BEI) Periode Tahun 2000-2002

Penelitian Rahayu (2002) yang menyimpulkan: Nilai Tukar dan Suku Bunga berpengaruh signifikan terhadap IHSG di BEI

Penelitian Krisnata (2009) yang menyimpulkan: IHSG 87,8\% dipengaruhi oleh LQ-45, sedangkan sisanya $12,2 \%$ berarti dipengaruhi oleh faktor lain, antara lain berupa faktor politik, fundamental perusahaan dan kebijakan pemerintah yang direspon pasar. Beberapa penelitian di atas adalah melihat pengaruh atau hubungan variabel independen terhadap indeks LQ45 atau indeks IHSG secara parsial. Sedangkan penelitian ini melihat hubungan kanonikal variabel independen terhadap indeks LQ45 dan indeks IHSG secara simultan. Oleh karenanya penelitian kanonikal lebih lengkap dibandingkan dengan penelitian secara regresi Banda. Contohnya penelitian Nugroho yang menyimpulkan bahwa suku bunga SBI berpengaruh positif terhadap Indeks LQ45. Penelitian Murni (2010) menyimpulkan bahwa Suku Bunga SBI berpengaruh negatif terhadap IHSG. Sedangkan penelitian kanonikal ini menyimpulkan bahwa variabel tingkat bunga SBI mempunyai hubungan yang negatif dan tinggi terhadap LQ45 dan IHSG secara simultan. Dengan kata lain, pada bila penelitian Nugroho melihat hubungan SBI (variabel X) dengan LQ45 (variabel Y) dan penelitian Murni melihat hubungan SBI (variabel X) dengan IHSG (variabel Y), maka penelitian kanonikal ini melihat hubungan SBI (variabel $\mathrm{X})$ dengan LQ45 (variabel $\mathrm{Y}_{1}$ ) dan IHSG (variabel $\mathrm{Y}_{2}$ ).

Indeks global (indeks Dow Jones dan EIDO) dan ekonomi makro (nilai tukar rupiah dan suku bunga SBI) mempunyai hubungan yang signifikan terhadap indeks pasar modal Indonesia (LQ45 dengan IHSG). Hal ini berarti bahwa indeks Dow Jones, EIDO, nilai tukar rupiah, suku bunga SBI berpengaruh atau menentukan LQ45 dan IHSG yang tercatat di Bursa Efek Indonesia pada periode 2011 sampai dengan 2013. Secara individual Indeks Dow Jones, Nilai Tukar Rupiah, dan suku bunga SBI mempunyai hubungan positif yang sangat tinggi terhadap indeks pasar modal Indonesia (LQ45 dengan IHSG), karena relatif stabilnya ketiga variabel tersebut. Sedangkan EIDO mempunyai pengaruh positif yang rendah karena masih belum tingginya minat investor di Amerika Serikat.

\section{REFRENSI}

Bodie, Z., Kane, A., and Marcus, A. J. 2002. Essentials Investment. McGraw-Hill: New York.

Darmadji, Tjiptono dan Hendy M. Fakhruddin. (2011). Pasar Modal Di Indonesia (Edisi 3). Jakarta: Salemba Empat.

Fahmi, Irfan dan Yovi Lavianti Hadi. (2009). Teori Portofolio dan Analisis Investasi (Edisi 2009). Bandung: Alfabeta.

Hariyani, Iswi dan R. Serfianto Dibyo Purnomo. (2010). Buku Pintar Hukum Bisnis Pasar Modal. Strategi Tepat Investasi Saham, Obligasi, Waran, Right, Opsi, Reksadana, dan 
Produk Pasar Modal Syariah (Edisi Pertama). Jakarta: Transmedia Pustaka.

Haryanto, M.Y Dedi, Riyatno. 2007. "Pengaruh Suku Bunga, Sertifikat Bank Indonesia, dan Nilai Kurs terhadap Resiko Sistemis Saham Perusahaan di BEJ". Jurnal Keuangan dan Bisnis.

Jogiyanto, Hartono. 2011. "Teori Portofolio dan Analisis Investasi. BPFE: Yogyakarta. Jorion, P. 1990. The Exchange Rate Exposure of US Multinational". Journal of Usiness, Vol. 63 No: 3.

Mankiw, Gregory N. 2006. Principles of Economics, Pengantar Ekonomi Makro. Edisi Ketiga. Alih Bahasa Chriswan Sungkono. Salemba Empat: Jakarta.

Boediono, Pengantar Ekonomi makro No.2 2001). BPFE UGM: yogyakarta

Sadono,Sukirno.2010. Makroekonomi. Teori pengantar. Edisi Ketiga.PT.Raja Grasido perseda. Jakarta

Mansyur, Moh. 2005. Pengaruh Indek Bursa Global terhadap Indek Harga Saham Gabungan (IHSG) pada Bursa Efek Jakarta (BEJ) Periode 2000-2002. Fakultas Ekonomi Univ. Padjajaran: Bandung.

Nugroho, Heru. (2008). Analisis Pengaruh Inflasi, Suku Bunga, Kurs dan Jumlah Uang Beredar terhadap Indeks LQ45 (Studi Kasus Pada BEI Periode 2002-2007). Semarang: Universitas Diponegoro.

Fahmi dan Hadi (2009:41) pasar modal.

Pohan, Aulia. 2008. Potret Kebijakan Moneter Indonesia. Cetakan Pertama. PT. Raja Grafindo: Jakarta. Samsul, Mohamad. 2006. Pasar Modal dan Manajemen Portofolio. Erlangga, Jakarta.

Sa'adah, Siti dan Yunia Panjaitan. 2006. "Interaksi Dinamis Antara Harga Saham dengan Nilai Tukar Rupiah terhadap Dollar Amerika Serikat". Jurnal Ekonomi dan Bisnis.

Salvatore, Dominick. 2008. Theory and Problem f Micro Economic Theory, 3rd Edition. Alih Bahasa oleh Rudi Sitompul. Erlangga: Jakarta.

Santoso, Singgih, 2010. Statistik Multivariat, Elex Media Komputindo, Jakarta. Satiningsih, Antik Darmayanti dan Teddy

Oswari. 2005. Pergerakan Harga Saham dan Pengukuran Pengembalian Risiko Saham BUMN. Universitas Gunadharma: Jakarta.

Siamat, Dahlan. (2005). Manajemen Lembaga Keuangan, Kebijalcan Moneter, dan Perbankan (Edisi Kelima). Jakarta: Lembaga Penerbit Fakultas Ekonomi Universitas Indonesia.

Sitinjak, Elyzabeth Lucky Maretha dan Widuri Kurniasari. 2003. "Indikator-indikator Pasar Saham dan Pasar Uang yang Saling Berkaitan Ditinjau dari Pasar Saham Sedang Bullish dan Bearish". Jurnal Riset Ekonomi dan Manajemen. Vol. 3 No. 3.

Sukirno, Sadono. (2010). Makroekonomi Teori Pengantar (Edisi 1). Jakarta: Rajawali Pers.

Tandelilin, Eduardus. (2007). Analisis Investasi dan Manajemen Portofolio (Edisi Pertama). BPFEVogyakarta.

Theresia Puji Rahayu. 2002. "Analisis Pengaruh Nilai Tukar dan Suku Bunga terhadap IHSG di BEI". Jurnal Ekonomi dan Bisnis Indonesia 15 (Juli) 